to detect small-scale genetic variation. In addition, samples from the European Continental Shelf (coasts of Britain, Portugal and Norway) will be collected in order to investigate large-scale differentiation. Genetic variation will be assessed with a combination of allozyme electrophoresis, Restriction Fragment Length Polymorphism (RFLP) analysis and analysis of sequence data of mtDNA.

We suspect a certain level of genetic differentiation between populations of the northern and southern part of the European Continental Shelf as gene flow between those populations is likely to be limited (isolation by distance). As for the Belgian Continental Shelf, a long-shore and offshore gradient in biotic and abiotic factors exists. This, along with its peculiar geomorphical structure (sand banks) which may or may not form a barrier for dispersal of the gobies, could influence the genetic structure of local populations.

Key words: gobies, population genetics, allozymes, mtDNA, RFLP analysis, Belgian Continental Shelf.

\title{
Organisation of microbenthic communities in interti- dal estuarine flats, a case study from the Molenplaat (Westerschelde Estuary, The Netherlands)
}

Ilse Hamels ', Koen Sabbe ', Koenraad Muylaert ',

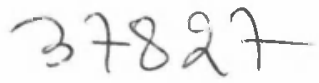
Christiane Barranguet ${ }^{2.4}$, Catherine Lucas ${ }^{3}$, Peter Herman ${ }^{4}$ \& Wim VYVERMAN '

'University of Gent, Department of Morphology, Systematics \& Ecology, Section Protistology and Aquatic Ecology, K.L. Ledeganckstraat 35, B-9000 Gent, Belgium

${ }^{2}$ University of Amsterdam, Department of Aquatic Ecotoxicology, Kruislaan 320, 1098 SM Amsterdam, The Netherlands

${ }^{3}$ University of Southampton, Department of Oceanography,

Southampton Oceanography Centre, European Way, Southampton, SO14 3ZH, U.K.

${ }^{4}$ Netherlands Institute of Ecology, Centre for Estuarine and Coastal Ecology, P.O. Box 140, 4401 AC Yerseke, The Netherlands

The auto- and heterotrophic microbenthic communities of a tidal flat in the Westerschelde estuary were studied at 4 stations in late spring and 
early autumn 1996. Additional information on the diatom component of these communities was obtained from a one-year survey of these organisms.

Total autotrophic biomass greatly exceeded heterotrophic biomass in late spring, especially at the more silty stations. However, in autumn, the auto-/heterotrophic biomass ratio was much lower and is $<1$ in the most sandy station. Epipelic diatoms generally comprised the bulk of primary producers, whereas epipsammic diatoms and flagellates only significantly contribute to autotrophic biomass in the more sandy sediments. Heterotrophic biomass was dominated by flagellates and ciliates. Sandy sediments had the most diverse ciliate communities and the highest biomass. The increase in ciliate biomass and the greater importance of herbivorous versus bacterivorous ciliates from June to September might be attributed to selective grazing by metazoa on the generally larger herbivorous ciliates in June. Preliminary estimates indicate that apart from episodic blooms of herbivorous taxa, ciliate grazing does not seem to have an important impact on epipelic diatom populations.

In general, silty sediments appear to be characterized by prominent temporal changes in microbenthic biomass and composition, related to predictable seasonal changes in environmental conditions as well as episodic and stochastic events resulting in severe disturbance and resuspension. Sandy sediments may have more complex and resilient microbenthic communities, adapted to a continuous regime of disturbance in the top layers of sediments and with a less pronounced seasonality.

\section{Arthropod populations occurring on the banks of the tidal part of the river Scheldt : distribution patterns and threats

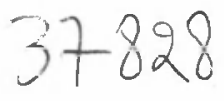

Frederik Hendrickx ${ }^{1,2}$, Jean-Pierre Maelfait ${ }^{2}$ \& Roald Steeno ${ }^{2}$

' University of Gent, Department of Biology, Laboratory of Ecology, Zoogeography and Nature Conservation, K.L. Ledeganckstraat 35, B-9000 Gent, Belgium

${ }^{2}$ Institute of Nature Conservation, Kliniekstraat 25, 1070 Brussels, Belgium

In contrast to other biota of the river Scheldt the terrestrial arthropod communities occurring on its banks were until recently very poorly 